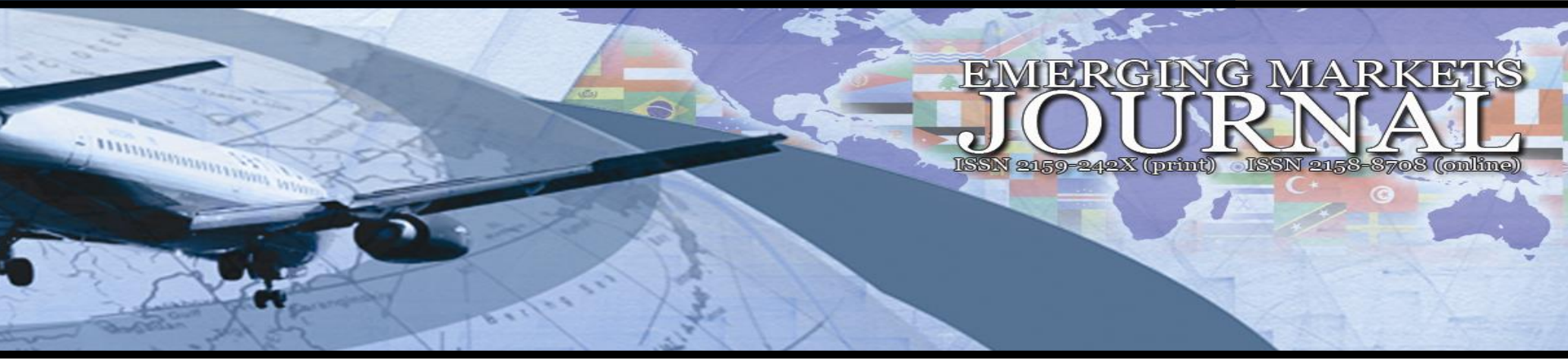

\title{
A Research on the Responsibility of Accounting Professionals to Determine and Prevent Accounting Errors and Frauds: Edirne Sample
}

\section{Semanur Adalı}

Istanbul University | semanuradali@gmail.com

\section{Cevdet Kızıl}

Istanbul Medeniyet University | cevdetkizil@yahoo.com

Volume 7 No 1 (2017) ｜ＩSSN 2158-8708 (online) ｜ＤOI 10.5195/emaj.2017.129 | http://emaj.pitt.edu |

\section{Abstract}

In this study, the ethical dimensions of accounting professionals related to accounting errors and frauds were examined. Firstly, general and technical information about accounting were provided. Then, some terminology on error, fraud and ethics in accounting were discussed. Study also included recent statistics about accounting errors and fraud as well as presenting a literature review. As the methodology of research, a questionnaire was distributed to 36 accounting professionals residing in Edirne city of Turkey. The collected data were then entered to the SPSS package program for analysis. The study revealed very important results. Accounting professionals think that, accounting chambers do not organize enough seminars/conferences on errors and fraud. They also believe that supervision and disciplinary boards of professional accounting chambers fulfill their responsibilities partially. Attitude of professional accounting chambers in terms of errors, fraud and ethics is considered neither strict nor lenient. But, most accounting professionals are aware of colleagues who had disciplinary penalties. Most important and effective tool to prevent errors and fraud is indicated as external audit, but internal audit and internal control are valued as well. According to accounting professionals, most errors occur due to incorrect data received from clients and as a result of recording. Fraud is generally made in order to get credit from banks and for providing benefits to the organization by not showing the real situation of the firm. Finally, accounting professionals state that being honest, trustworthy and impartial is the basis of accounting profession and accountants must adhere to ethical rules.

Keywords: Accounting, Accounting Professionals, Error, Fraud, Edirne

$(\mathrm{cc}) \mathrm{EY}$

New articles in this journal are licensed under a Creative Commons Attribution 3.0 United States License.

\section{UILIS D-Sult}

This journal is published by the University Library System of the University of Pittsburgh as part of its $\underline{\mathrm{D} \text {-Scribe Digital Publishing Program, and is cosponsored by the University of Pittsburgh Press. }}$. 


\section{A Research on the Responsibility of Accounting Professionals to Determine and Prevent Accounting Errors and Frauds: Edirne Sample}

\section{Semanur Adalı \\ Cevdet Kızıl}

\section{1- Introduction}

Accounting explains the financial situation of an organization, produces information about the firm's situation as well as transmitting this information to related individuals or organizations (Sevilengül, 2016). Accounting represents the process of recording, classifying, summarizing, reporting, and commenting financial transactions and events expressed in monetary terms. Accounting records processes and events which can be expressed with money. The first financial transaction of an organization is related to capital investment. Recording in accounting is realized with journal entries. Then, accounting also has the classifying (categorizing) function which is realized with ledger. In terms of summarizing function, accounting takes advantage of trial balance. Also, information which is produced in an accounting information system related to organization is presented to related groups with a global language. Investors, creditors, government and regulatory bodies all take advantage from the mentioned language. Accounting realizes the reporting function with main and assisting financial statements. Finally, accounting has the commenting function, which is realized by providing necessary interpretations based on financial statements. The mentioned accounting function is very crucial and critical in today's business world. (Kızıl \& Kızıl, 2007).

Financial statements of an organization emerge by the help of accounting processes. The International Accounting Standards Committee (IASC) has acknowledged that the purpose of financial statements is to offer information about the financial position, performance and capability of an enterprise that is valuable to a wide range of users in making economic decisions (Elliott \& Elliott, 2011). Accounting is classified to three sub categories which are financial accounting, managerial accounting and cost accounting. There are some differences among them. Financial accounting is responsible for announcing the financial situation of an organization to other parties which means external parties, whereas cost accounting and managerial accounting is responsible for providing information to the executives in an organization for healthy decision making (Sevilengül, 2016). While financial accounting is back-wise, managerial accounting is forward-wise to report the mathematical records and calculations. Managerial accounting benefits from financial accounting to foresee the future of organization due to the fact that it includes the previous information about the organization. Besides, managerial accounting classifies organizations as merchandise, manufacturing and service companies as well as making calculations about the future according to that classification (Büyükmirza, 2016).

In 2008, a new regulation was in effect classifying accountants only as Certified Public Accountant (CPA) or Sworn-in Public Accountant (SPA) in Turkey. Before this regulation, in addition to these titles, there were also Professional Accountants based on the law that was published in 1989. CPAs keep the books, prepare balance sheets, profit and loss statements in addition to other documents, in accordance with Generally Accepted Accounting Principles (GAAPs) and relevant legislative provisions. CPAs are also responsible for establishing or developing accounting systems, arranging issues related to business administration, accounting, finance, financial legislation and their applications or consulting on these issues. Further, CPAs are responsible for analyzing, conducting audits, giving written opinions on financial statements and declarations, besides organizing reports. There are important differences between CPAs and SPAs. Sworn-in Public Accountants can't keep books related to accounting, they can't operate an accounting office and they can't be partners in accounting offices (TURMOB, 2017). Sworn-in Public Accountants also can't establish or develop accounting systems.

Accounting professionals are communicators to transform the information for global language in accounting. Accountancy is the art of communicating financial information about a business unit to users such as shareholders and managers. The communication is generally in the form of financial statements. Financial statements are prepared in monetary terms showing economic resources under the control of administration. Selecting the information should be relevant to the user 
and data contained on financial statements should also be reliable. Shareholders require periodic information about the firm and they need to be sure that managers are working properly for the resources under their control. This information helps shareholders to evaluate the performance of managers (Elliott \& Elliott, 2011).

Accounting professionals are responsible towards their colleagues, customers and the public, since they are obliged to comply with ethical rules during their work. As in other professions, there may be some uncertainties in practice in the accounting profession, sometimes related to ethical responsibilities. In order to overcome these uncertainties, efforts are being made to establish rules of professional ethics in Turkey and in the international area (Bayraktar, 2007). Regulations on accounting ethics were made by TÜRMOB, the Ministry of Finance and the Capital Markets Board (CMB) on the national arena of accounting professional ethics in Turkey. It is aimed to direct the behaviors of members of these professions parallel to these regulations. In the international platform, the principles and rules developed by International Federation of Accountants (IFAC) and American Institute of Certified Public Accountants (AICPA) have made important contributions to accounting ethics (Karaman, 2015) .

Accounting errors refer to unsuitable behaviors against Generally Accepted Accounting Principles (GAAPs). Errors do not include any intention, but there exists unawareness and neglect. In other words amnesia, carelessness, unawareness, neglect and inexperience cause errors in accounting. However, sometimes it is a hard job to determine if it is an error or a fraud. If there is no proof for intention, then it is called an error. In case there is an error, that should definitely be corrected (Bayraklı, Erkan, \& Elitaş, 2012).

Potential current period errors which are discovered in that period must be corrected before the financial statements are authorized and published. Still, material errors sometimes cannot be discovered until a subsequent period, and these prior period errors are corrected in the relative information presented in the financial statements of the period succeeding (Marcos \& Tayse, 2013). There is also a difference between error and fraud in the formation of the spiritual element of the crime. According the Tax Procedure Law, errors are not subject to penalties. Generally, errors are made on accounting records while frauds are made on documents intentionally (Erdoğan, Elitaş, Erkan, \& Aydemir, 2014).

Fraud is to act in contradiction to national or international legislation. As it is stated formerly, the definition of fraud includes intention (Erdoğan, Elitaş, Erkan, \& Aydemir, 2014). Business frauds have both financial and non-financial evil results. The results of fraudulent financial reporting have become more visible, especially in the last 10-15 years. Moreover, accounting deeds lead to the inefficiency of capital markets. As a result, disadvantages in the distribution of economic resources occur (Anuk, 2015).

At this point, the fraud triangle which originated from Donald Cressey's hypothesis should also be mentioned. Trusted individuals sometimes become trust violators when they have a financial problem, which is nonshareable. Mentioned individuals are in some situations responsive to this problem by hurting the financial trust. There are three factors that must be present simultaneously in order for an ordinary person to commit fraud (ACFE, 2017).

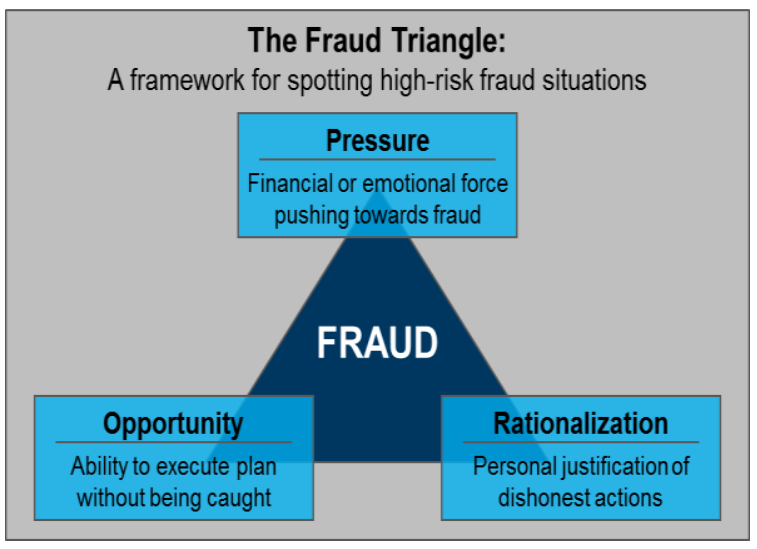

Figure 1. The Fraud Triangle

Resource: Brumellgroup, 2015

Pressure: Managers often want to show good financial results. This is because wages, premiums and revenues depend on financial results and performance. Employees may need a lot of money for different reasons, so they do fraud. Such pressures emerge from personal and monetary interests.

Opportunity: The most important leg of the trick triangle is the opportunity to cheat on the employees' businesses. Each entity has assets that have various characteristics. These assets are in constant circulation as a matter of necessity. For this reason, it is possible that assets are in some way under the control of, for example, business associates, sellers or customers. For this reason, there is always an opportunity for fraud.

Rationalization: When there is an excuse for fraud behavior, it will serve as a bridge between oppression and opportunity. Those who commit fraud say themselves: "Everyone does, I do not hurt anyone, I try to justify myself by hiding behind the agenda I make for the company" (Yardımcıoğlu, Koca, Günay, \& Kocamaz, 2014).

Some features of individuals who committed fraud were investigated by Association of Certified Fraud Examiners (ACFE) with studies run in 2012, 2014 and 
2016. The results of these studies are indicated with figures and relative comments below.

\section{Gender Distribution Perpetrator}

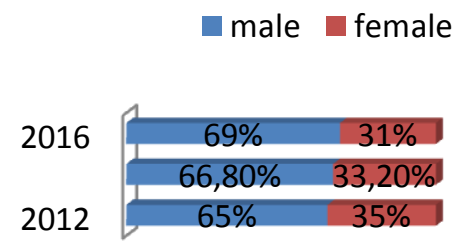

Figure 2. Gender Distribution Perpetrator Resource: ACFE, 2016

According to the report which was published by ACFE in 2016, males commit fraud more than females. As it is easy to recognize, males committed fraud more than females in all periods, which were 2012, 2014 and 2016. We can expect the possibility of fraud to increase, because males are generally more likely to take higher positions compared to females and they are still more effective in business decisions.

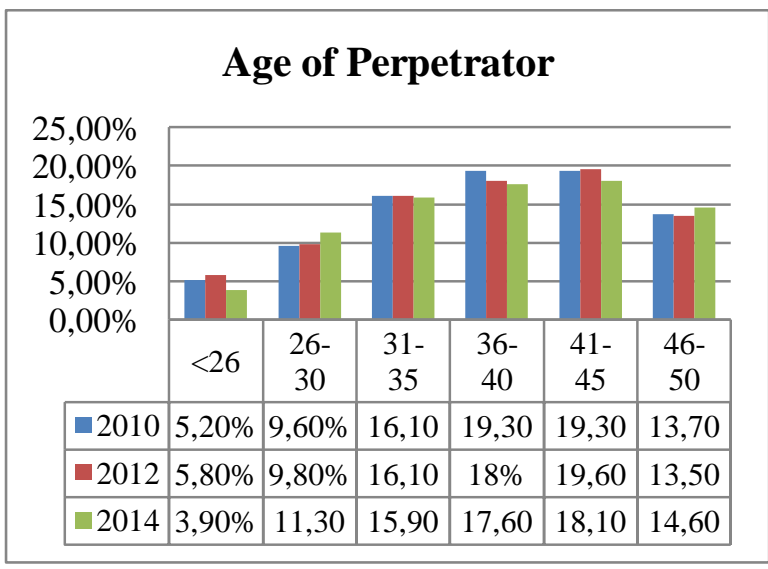

Figure 3. Age of Perpetrator

Resource: ACFE, Report to the Nations, 2014

According to the report which is published by the Association of Certified Fraud Examiners (ACFE), it is seen that employees aged 41-45 are more likely to commit fraud compared to other age groups. For this reason, we can commend that the 41-45 age group is more ambitious and they seem to have more reasons for making money as well as guaranteeing their future.

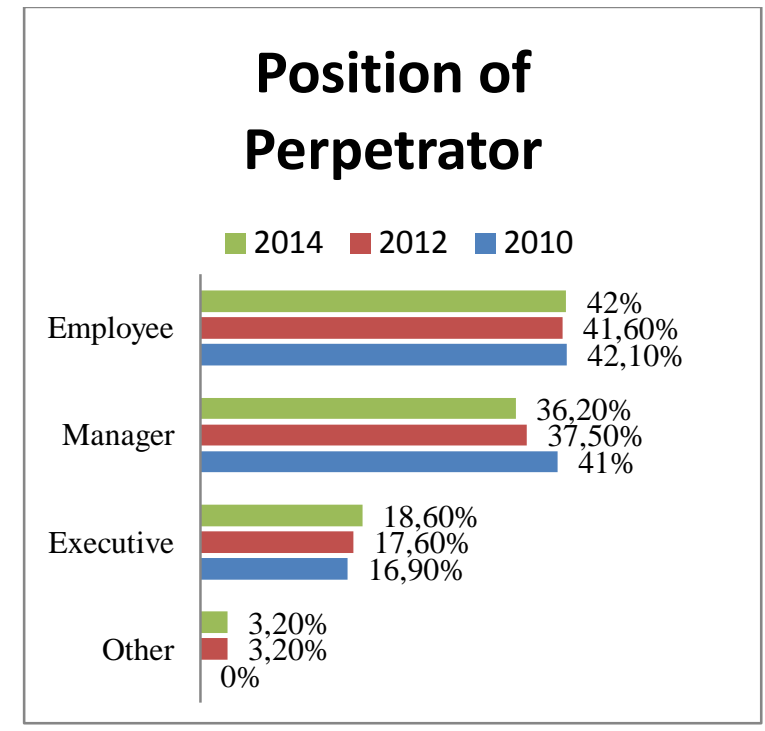

Figure 4. Position of Perpetrator

Resource: ACFE, Report to the Nations, 2014

The frequency of fraud performed in business also varies according to positions. As it can be seen from the figure above, fraud is mostly committed by employees. They are followed by managers and executives. The most common reason for this is the fact that, employees are authorized to access funds and assets. These personnel, who are trusted because of their long working periods and positions in the firm, are sometimes kept away from the control mechanism and commit fraud by abusing this confidence (Anuk, 2015) . Furthermore, it can be commented that employees are paid lower compared to managers and executives, so they sometimes don't have much to lose. On the other hand, a manager or executive generally has many things to lose, which definitely keeps him away from committing fraud.

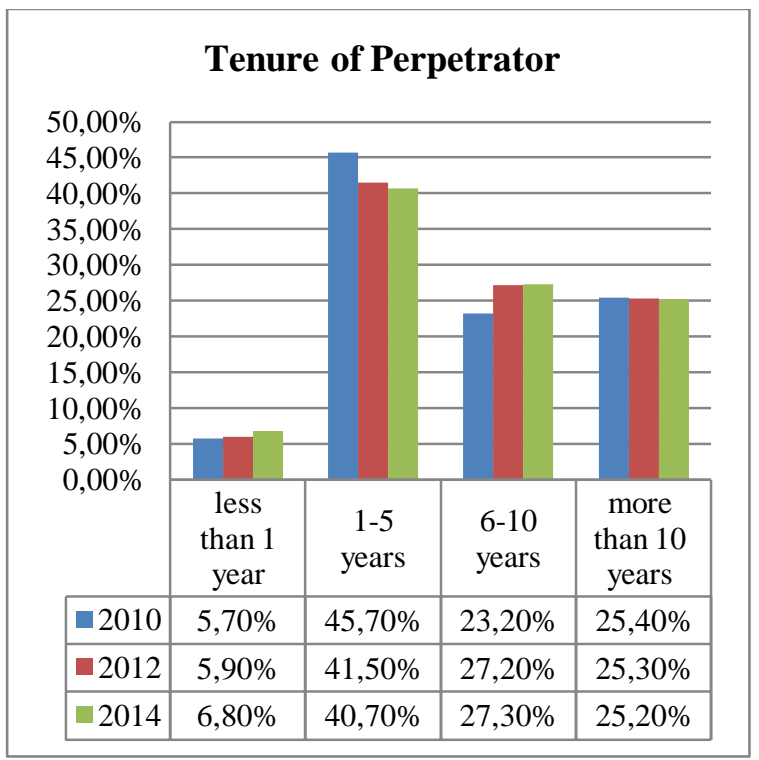

Figure 5. Tenure of Perpetrator

Resource: ACFE, Report to the Nations, 2014 
According the results of fraud report which was published by ACFE in 2014, the highest rate of fraud is observed for 1-5 years of experience (tenure). The rate of fraud is lower for 6-10 years and more than 10 years' experience (tenure).
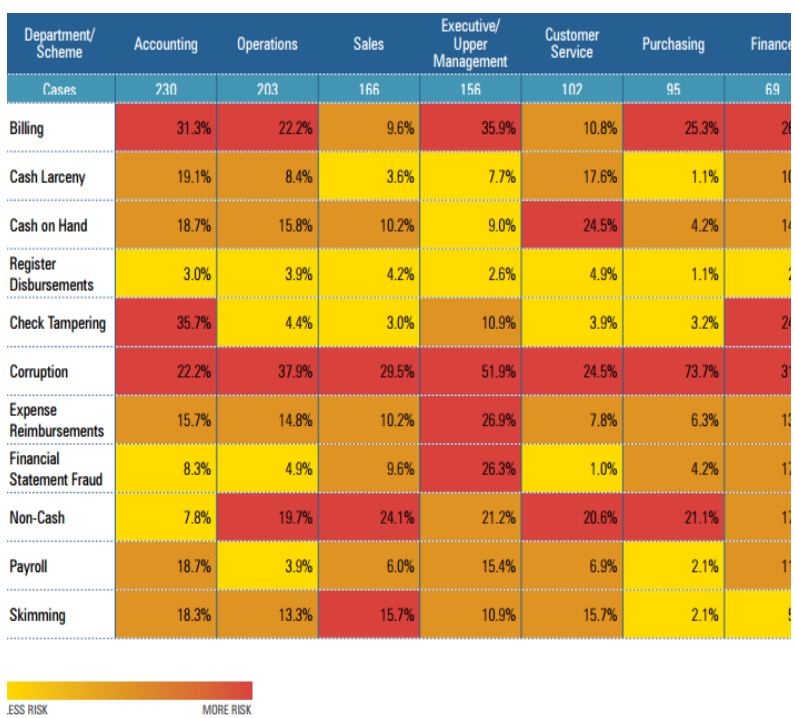

\section{Figure 6. Frequency of Schemes Based on Perpetrator's Department \\ Resource: ACFE, Report to the Nations, 2014}

When the table above is examined, it can be observed that accounting department has the highest rate for frauds in 2014, which is then followed by the operations department. On the other hand, finance department is subject to lower rates of fraud. Also, corruption is indicated as most risky in terms of fraud format.

The second part of this study continues with Literature Review. Third section includes Data and Methodology of research. Fourth section is the Conclusion, which discusses results and recommendations for future research.

\section{Literature Review}

A research was run by Köpri, Civan and Kara in 2016, which examined fraud risk on financial statements. Their research investigated firms that were traded in Borsa Istanbul (BIST) - Istanbul Stock Exchange. Factors determining the fraud risk were revealed. Categorical dependent variable was created by coding firms that carry the risk of ailing and firms which do not carry the risk of fraud. A data set was created with 10 independent variables selected from the literature. According to the results of the analysis, differences among groups were observed in which the variables did not show normal distribution. It has been found that, all the variables are different among groups that carry the cheating risk and which do not carry the cheating risk. A statistically significant relationship was found among turnover rate, financial leverage ratio, gross profit margin, firm size, trading period and fraud risk variables. On the other hand, there was a negative relationship between the big four (Big 4) audit firms and risk of fraud (Köpri, Civan, \& Kara, 2016).

Another research was run by Özcan in 2016. The study which is about firm characteristics and accounting frauds reveal variables such as assets, current ratio, working capital to total assets, return on assets, return on equity, profit margin, debt to equity, accounts receivable turnover, inventory turnover ratio and interest coverage ratio. The proposed multivariate model has a satisfactory performance in correctly identifying the firms that commit accounting fraud. An accurate and reliable model that identifies fraudulent financial statements would serve as a critical analytical tool for fraud investigators. Early detection of accounting frauds helps government authorities in maintaining the stability of financial markets. The results of analysis indicate that accounting ratios can shed light on the probability of financial statements fraud. With more sophisticated empirical models and a greater number of accounting ratios, it is possible to create a more effective empirical model (Özcan, 2016).

Kızıl, Çelik, Akman and Şener made a study about creative accounting methods and manipulation of financial information in 2016. The research conducted interviews with certified public accountants (CPAs) and internal auditors, which included questions about creative accounting and manipulation of financial data. According to the results of study, leading results of accounting manipulation were insufficient internal control system, inadequate external auditing team, personal interests of managers, weak management structure, personal expectations of accounting professionals, career and monetary concerns, low knowledge level of accountants and concern of firms to find necessary funds (K1zıl, Çelik, Akman and Şener, 2016).

According to a study which was run by Anuk in 2015 at Istanbul, when the age of accounting professionals goes up, agreement level on ethics about accounting increases. Also, this study's participants agreed that, the most important factors to prevent errors and frauds were internal audit and independent audit. The leading reasons of errors were indicated as lack of personnel attention, recording mistakes and incorrect data. When the reason of frauds was examined, purpose of tax evasion had the highest percentage. Moreover, frauds were made in order to benefit the business by not showing the real situation of company, as well as counterfeiting document editing and using (Anuk, 2015).

In 2015, a research was run by K1z1l, Akman, Aras and Erzin about the accounting ethics perception of 
accounting professionals residing in Yalova. For the study, survey forms were distributed to 40 accountants living in Yalova and 32 of them returned the questionnaire sheets. Thus, the return rate of questionnaire as the research methodology was $80 \%$. Research data were then entered to the SPSS program and reports were received. The research questionnaire used 5-point Likert Scale. Most of the questionnaire respondents were male, between 30-39 years old, had undergraduate degree, CPA title, had more than 15 years of experience and owned more than 50 clients. Based on the results of research, it was found that accounting professionals in Yalova were generally not insensitive to ethics and professional ethics issues. They were mainly trying to improve themselves concerning the ethical concepts. It was determined that, accounting professionals were following ethical principles at several points. However, ethical guidelines were disregarded on some specific subjects (Kızıl, Akman, Aras and Erzin, 2015).

Another research was made in the Mediterranean Region by Keskin in 2014. The main reason of errors and frauds were explained. According to the study, constant changes in the legislation increase the risk of mistakes by members of profession. Another reason of errors was shown to be numerical ones. Then, it was emphasized that, some errors occur because law and regulation provisions are not always followed up to date. For frauds, almost $50 \%$ of respondents agree that, informal processes without documents are eye-catching reasons. Also, accountant professionals who participated in the survey agreed that, there should not be big differences between the daily cash collections of enterprises and bank reports (Keskin, 2014).

A research was made by Başkan in 2013 at İstanbul. This study concentrated on big companies and revealed that, most important tools used in determining errors and frauds were internal auditing, internal control and independent auditing. As type of frauds, the most commons were disguised debt and liabilities, counterfeit incomes and wrong evaluations of assets. Also some techniques to detect fraud used by accounting professionals were stated in this study. The most common used techniques were inventory technique, customer observation technique and examination of documents method. There were also some results and findings for enhancing audit effectiveness. These were audit rotation, commitment to accounting standards, detailed analysis of client business and obtaining information from the client's previous auditor (Baskan, 2013).

According to a study run by Okay in 2011 at Diyarbakır, the main reasons of errors in accounting were shown as ignorance and no attention. Most of the accounting professionals thought that, just auditing was not enough to detect errors and frauds in accounting. Most accounting professionals said that, one of the leading reasons of fraud was to get more loans from credit institutions. In other words, firm were sometimes committing fraud to get credits from banks. Also, motivations to pay less tax were shown as another reason (Okay, 2011).

A crucial technique was emphasized in another study by Kirkos, Spathis and Manolopoulos in 2007 to detect fraud in accounting. The aim of this study was to investigate the usefulness and compare the performance of three data mining techniques in detecting fraudulent financial statements by using published financial data. The results which were obtained from the experiments pointed out similar findings with previous research results. They showed that published financial statement data contain fraudulent indicators. This information, coupled with data mining algorithms, can provide models capable of achieving considerable classification accuracies. The use of proposed methodological framework could be help to auditors, both internal and external, taxation and other state authorities, individual and institutional, investors, stock exchange, law firms and banking systems (Kirkos, Spathis, \& Manolopoulos, 2007).

Another study was run by Kirik in 2007 at Afyonkarahisar about accounting errors and frauds. According to data results, the main reasons of errors were carelessness, ignorance and heavy workload. A great majority of accounting professionals thought that, the source of errors was actually employers, not themselves. Another reason of errors was tight tax reporting periods. This was always equivalent to high workload and risk. The changes in tax laws also caused differences in interpretation. Moreover, most of accounting professionals thought that just audit was not enough to prevent errors and frauds. In this research, accounting professional reported that they had experienced balance sheet mask requests as high as $49 \%$ even though Afyonkarahisar had mainly small and medium-sized enterprises. The main reasons of this situation were trying to get more loans from banks and paying low taxes (Kirik, 2007).

Another research was published by Bierstake, Brody and Pacini in 2006, which investigated the extent to which accountants, internal auditors, and certified fraud examiners use assorted fraud prevention and detection methods and software, as well as their perceptions for fraud detection. The results did put forward that firewalls, virus and password protection, and internal control review and development were quite frequently used to battle fraud. Nonetheless, continuous auditing, discovery sampling, data mining, forensic accounting, 
and digital analysis software were less often used, notwithstanding receiving the high ratings of usefulness. Especially, organizational use of forensic accountants was the least often used of any anti-fraud method, but had the highest mean effectiveness rating. Smaller firms came into view to be the most unwilling to supply in fraud prevention and revealing methodology. This could be because of concerns about cost, although a fraud incident can be more costly for small businesses than large ones. The results pointed out that even at larger firms; anti-fraud methods and software were underutilized (Bierstaker, Brody, \& Pacini, 2006).

Durtschi, Hillison and Pacini's research in 2004 emphasized that; Benford Law was effective to detect accounting frauds. The goal of this study was to help auditors more appropriately for applying Benford's lawbased analysis to boost their ability to identify fraud. It was concluded that when used correctly, Benford's analysis is a useful tool to detect suspicious accounts. It was also stated that, due to its helpfulness, digital analysis tools based on Benford's law were now included in many popular software packages and were being touted in the popular press. It was also mentioned that, Benford Law was helpful to identify possible errors, potential fraud or other irregularities. Benford analysis was a particularly useful analytical tool because it does not use aggregated data; rather it is conducted on specific accounts using all the data available. It can be very useful in identifying specific accounts for further analysis and investigation (Durtschi, Hillison, \& Pacini, 2004).

The study which was conducted by Knapp and Knapp in 2001 provided empirical tests of experience and unambiguous fraud risk. This study also focused on auditors' ability to use analytical procedures to successfully assess the risk of falsified financial reporting. Audit managers and seniors were asked to read either a fraud case or a no fraud case, perform an analytical procedures task, and provide fraud risk assessments. With respect to experience, audit managers were significantly more efficient in assessing the risk of financial statement fraud with analytical procedures than audit seniors. Furthermore, risk assessments of audit seniors did not differ significantly when fraud was present or was not present. With respect to explicit fraud risk assessment instructions, the results indicated that auditors' fraud risk assessments were more effective when explicit fraud risk assessment instructions were present (Knapp \& Knapp, 2001).

One of the earliest studies in literature by Bonner, Palmrose and Young dated 1998 stated the importance of fraud type to detect frauds. It documents that, fraud type matters in auditor's legal action and provides proof on specific characteristics of fraud. Documenting fraud type is a required first step to better comprehend the role of fraud in auditor's legal action (Bonner, Palmrose, \& Young, 1998).

\section{Data and Methodology}

This study took advantage of the questionnaire method in terms of implementation section. In this regard, surveys were distributed to 36 accounting professionals residing in the city of Edirne, Turkey. Responsibility of accounting professionals to determine and prevent accounting errors and fraud was investigated. Research results and findings are presented on tables below:

Table 1: Age

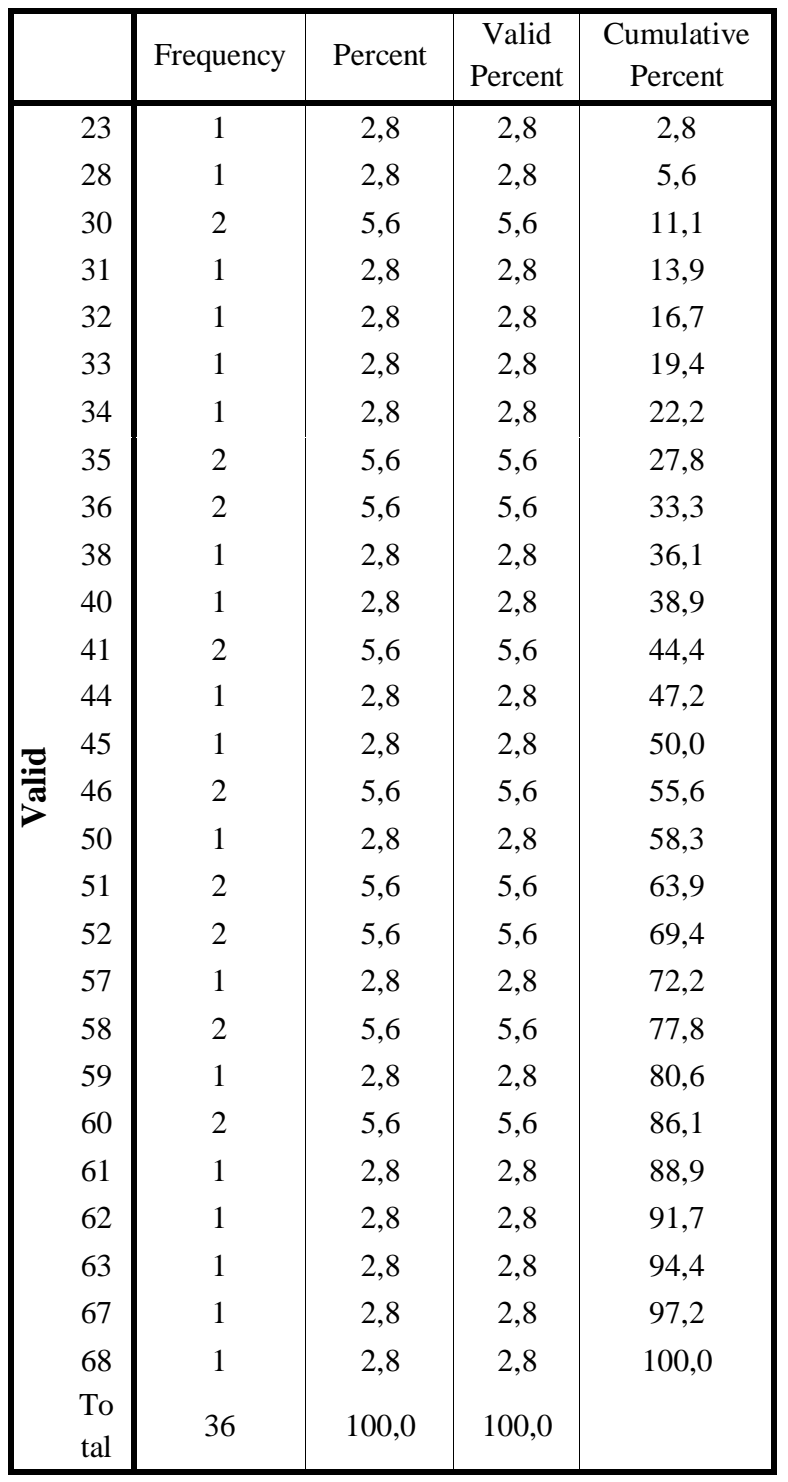

As observed on Table 1, 50\% of accounting professionals completing the questionnaire were over 45 years old. Therefore, we can say that the average age was not young and low for accounting professionals in Edirne, who were subject to this study. 
Table 2: Gender

\begin{tabular}{|cc|c|c|c|c|}
\hline & Frequency & Percent & $\begin{array}{c}\text { Valid } \\
\text { Percent }\end{array}$ & $\begin{array}{c}\text { Cumulative } \\
\text { Percent }\end{array}$ \\
\hline \multirow{2}{*}{} & male & 26 & 72,2 & 72,2 & 72,2 \\
& female & 10 & 27,8 & 27,8 & 100,0 \\
& Total & 36 & 100,0 & 100,0 & \\
\hline
\end{tabular}

For the Edirne sample, Table 2 shows that $72,2 \%$ of accounting professionals were males. On the other hand, $27,8 \%$ of accounting professionals subject to this study were females.

Table 3: Job title

\begin{tabular}{|c|c|c|c|c|}
\hline & Frequency & Percent & $\begin{array}{c}\text { Valid } \\
\text { Percent }\end{array}$ & $\begin{array}{c}\text { Cumulative } \\
\text { Percent }\end{array}$ \\
\hline \multirow{2}{*}{$\begin{array}{c}\text { Professional } \\
\text { Accountant } \\
\text { Certified } \\
\text { Public } \\
\text { Accountant } \\
\text { Total }\end{array}$} & 3 & 8,3 & 8,3 & 8,3 \\
& 36 & 100,0 & 100,0 & 100,0 \\
\hline
\end{tabular}

As mentioned earlier in the literature review section, according to a new regulation published in 2008, accounting professionals are now classified as Certified Public Accountant (CPA) or Sworn-in Public Accountant (SPA) in Turkey. Before this regulation, there were also Professional Accountants. Therefore, Edirne sample subject to this study only included 3 Professional Accountants. No Sworn-in-Public Accountant (SPA) residing in Edirne participated in this study.
Table 4: Experience of Accounting Professionals (number of years in occupation)

\begin{tabular}{|c|c|c|c|c|c|}
\hline & Frequency & Percent & Valid Percent & $\begin{array}{c}\text { Cumulative } \\
\text { Percent }\end{array}$ \\
\hline \multirow{27}{*}{$\frac{\pi}{\frac{\pi}{7}}$} & 1 & 1 & 2,8 & 2,8 & 2,8 \\
\hline & 3 & 2 & 5,6 & 5,6 & 8,3 \\
\hline & 4 & 1 & 2,8 & 2,8 & 11,1 \\
\hline & 6 & 2 & 5,6 & 5,6 & 16,7 \\
\hline & 7 & 2 & 5,6 & 5,6 & 22,2 \\
\hline & 8 & 1 & 2,8 & 2,8 & 25,0 \\
\hline & 9 & 1 & 2,8 & 2,8 & 27,8 \\
\hline & 10 & 2 & 5,6 & 5,6 & 33,3 \\
\hline & 11 & 1 & 2,8 & 2,8 & 36,1 \\
\hline & 15 & 1 & 2,8 & 2,8 & 38,9 \\
\hline & 16 & 1 & 2,8 & 2,8 & 41,7 \\
\hline & 17 & 1 & 2,8 & 2,8 & 44,4 \\
\hline & 18 & 2 & 5,6 & 5,6 & 50,0 \\
\hline & 20 & 2 & 5,6 & 5,6 & 55,6 \\
\hline & 21 & 1 & 2,8 & 2,8 & 58,3 \\
\hline & 25 & 1 & 2,8 & 2,8 & 61,1 \\
\hline & 27 & 1 & 2,8 & 2,8 & 63,9 \\
\hline & 28 & 2 & 5,6 & 5,6 & 69,4 \\
\hline & 30 & 1 & 2,8 & 2,8 & 72,2 \\
\hline & 31 & 1 & 2,8 & 2,8 & 75,0 \\
\hline & 34 & 2 & 5,6 & 5,6 & 80,6 \\
\hline & 35 & 2 & 5,6 & 5,6 & 86,1 \\
\hline & 37 & 1 & 2,8 & 2,8 & 88,9 \\
\hline & 40 & 1 & 2,8 & 2,8 & 91,7 \\
\hline & 42 & 2 & 5,6 & 5,6 & 97,2 \\
\hline & 43 & 1 & 2,8 & 2,8 & 100,0 \\
\hline & Total & 36 & 100,0 & 100,0 & \\
\hline
\end{tabular}

As observed on Table 4, accounting professionals have a high experience in their fields. According to the ACFE report published in 2014, accounting professionals who have over 10 years of experience do not reflect a very high rate for fraud tendency. High working experience also depends on high age range.

Table 5: Education Level (Education Status) of Accounting Professionals

\begin{tabular}{|c|c|c|c|c|c|}
\hline & & Frequency & Percent & $\begin{array}{l}\text { Valid } \\
\text { Percent }\end{array}$ & $\begin{array}{c}\text { Cumulative } \\
\text { Percent }\end{array}$ \\
\hline \multirow{5}{*}{$\underset{7}{\stackrel{7}{\rightleftharpoons}}$} & $\begin{array}{l}\text { Commercial } \\
\text { high school }\end{array}$ & 7 & 19,4 & 19,4 & 19,4 \\
\hline & Associate degree & 2 & 5,6 & 5,6 & 25,0 \\
\hline & Bachelor degree & 25 & 69,4 & 69,4 & 94,4 \\
\hline & $\begin{array}{l}\text { Postgraduate } \\
\text { degree }\end{array}$ & 2 & 5,6 & 5,6 & 100,0 \\
\hline & Total & 36 & 100,0 & 100,0 & \\
\hline
\end{tabular}


When the education level (education status) of accounting professionals residing in Edirne is analyzed, it is observed that $69,4 \%$ of accounting professionals have a bachelor degree. This is followed by accounting professionals who has the commercial high school diploma, which is equivalent to $19,4 \%$. Accounting professionals who have associate degree and postgraduate degree has the same percentage of 5,6\%.

Table 6: Number of Employees in Organizations (Accounting Firms)

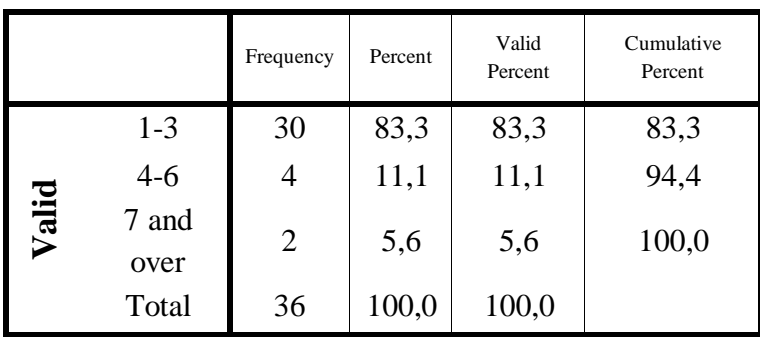

When the number of employees in organizations (accounting offices) are investigated, between 1-3 employee(s) option has the highest rate, which is equivalent to $83,3 \%$. Between 4-6 employees option is ranked second with $11,1 \%$, and then 7 and over employees option ranks third with the lowest rate of $5,6 \%$.

Table 7: Number of Clients

\begin{tabular}{|c|c|c|c|c|c|}
\hline & & Frequency & Percent & $\begin{array}{l}\text { Valid } \\
\text { Percent }\end{array}$ & $\begin{array}{l}\text { Cumulative } \\
\text { Percent }\end{array}$ \\
\hline \multirow{6}{*}{ 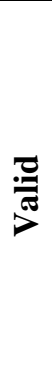 } & $\begin{array}{c}30 \\
\text { and } \\
\text { below }\end{array}$ & 10 & 27,8 & 27,8 & 27,8 \\
\hline & $31-60$ & 14 & 38,9 & 38,9 & 66,7 \\
\hline & $61-90$ & 6 & 16,7 & 16,7 & 83,3 \\
\hline & $\begin{array}{c}91 \\
\text { and }\end{array}$ & 6 & 167 & 167 & 100 \\
\hline & over & & & & \\
\hline & Total & 36 & 100,0 & 100,0 & \\
\hline
\end{tabular}

When number of clients of accounting professionals are examined, it is observed that $38,9 \%$ of accounting professionals have clients between 31 and 60 . 27,8\% have 30 clients and below. Then, $16,7 \%$ of accounting professionals have 61-90 customers and 91 and over clients.
Table 8: Employees with Penalty Records in Organizations

\begin{tabular}{|cc|c|c|c|c|}
\hline & Frequency & Percent & Valid Percent & Cumulative Percent \\
\hline 플 & Yes & 5 & 13,9 & 13,9 & 13,9 \\
$>$ & No & 31 & 86,1 & 86,1 & 100,0 \\
& Total & 36 & 100,0 & 100,0 & \\
\hline
\end{tabular}

According to Table 8, $13,9 \%$ of accounting professionals have employees with penalty records in their organizations. However, $86,1 \%$ of accounting professionals do not have employees with penalty records.

Table 9: Opinion of Accounting Professionals about the Adequacy of Seminars/Conferences Organized by Accounting Chambers on Errors and Fraud

\begin{tabular}{|cc|c|c|c|c|}
\hline & Frequency & Percent & Valid Percent & Cumulative Percent \\
\hline & Yes & 11 & 30,6 & 30,6 & 30,6 \\
\hline & No & 25 & 69,4 & 69,4 & 100,0 \\
& Total & 36 & 100,0 & 100,0 & \\
\hline
\end{tabular}

According to Table 9, 30,6\% of accounting professionals believe that accounting chambers organize adequate seminars/conferences on errors and fraud. On the opposite side, $69,4 \%$ of accounting professionals think that accounting chambers do not organize enough seminars/conferences on errors and fraud.

Table 10: Opinions of Accounting Professionals whether Supervision and Disciplinary Boards of Professional Accounting Chambers fulfill their Responsibilities

\begin{tabular}{|c|c|c|c|c|c|}
\hline & & Frequency & Percent & $\begin{array}{l}\text { Valid } \\
\text { Percent }\end{array}$ & $\begin{array}{l}\text { Cumulative } \\
\text { Percent }\end{array}$ \\
\hline \multirow{4}{*}{$\frac{\pi}{7}$} & Yes & 11 & 30,6 & 30,6 & 30,6 \\
\hline & No & 4 & 11,1 & 11,1 & 41,7 \\
\hline & Partially & 21 & 58,3 & 58,3 & 100,0 \\
\hline & Total & 36 & 100,0 & 100,0 & \\
\hline
\end{tabular}

When answers of participants are examined on the responsibilities of supervision and disciplinary boards of professional accounting chambers, 58,3\% think that professional accounting chambers fulfill their responsibilities partially, 30,6\% believe the chambers fulfill their responsibilities and $11,1 \%$ state that chambers don't fulfill their responsibilities. 
Table 11: Attitude of Professional Accounting Chambers in terms of Errors, Fraud and Ethics

\begin{tabular}{|c|c|c|c|c|c|}
\hline & & Frequency & Percent & $\begin{array}{l}\text { Valid } \\
\text { Percent }\end{array}$ & $\begin{array}{c}\text { Cumulative } \\
\text { Percent }\end{array}$ \\
\hline \multirow{7}{*}{$\frac{\pi}{>}$} & Strict & 3 & 8,3 & 8,3 & 8,3 \\
\hline & neither & & & & \\
\hline & strict nor & 19 & 52,8 & 52,8 & 61,1 \\
\hline & 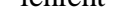 & & & & \\
\hline & Lenient & 12 & 33,3 & 33,3 & 94,4 \\
\hline & $\begin{array}{c}\text { strongly } \\
\text { lenient }\end{array}$ & 2 & 5,6 & 5,6 & 100,0 \\
\hline & Total & 36 & 100,0 & 100,0 & \\
\hline
\end{tabular}

Based on Table 11, 52,8\% of accounting professionals believe that attitude of professional accounting chambers in terms of errors, fraud and ethics is neither strict nor lenient. 33,3\% think attitude of professional accounting chambers in terms of errors, fraud and ethics is lenient. These are followed by the opinions of strict (8,3\%) and strongly lenient (5,6\%).

Table 12: Colleagues of Accounting Professionals who had Disciplinary Penalties

\begin{tabular}{|cc|c|c|c|c|}
\hline & Frequency & Percent & Valid Percent & $\begin{array}{c}\text { Cumulative } \\
\text { Percent }\end{array}$ \\
\hline Yes & 25 & 69,4 & 69,4 & 69,4 \\
글 & No & 11 & 30,6 & 30,6 & 100,0 \\
& Total & 36 & 100,0 & 100,0 & \\
\hline
\end{tabular}

Table 12 indicates that, 69,4\% of accounting professionals were aware of their colleagues who had disciplinary penalties. However, $30,6 \%$ of accounting professionals reported the opposite.

Table 13: Most Important and Effective Tools to Prevent Errors and Fraud

\begin{tabular}{|c|c|c|c|c|c|}
\hline & Frequency & Percent & $\begin{array}{l}\text { Valid } \\
\text { Percent }\end{array}$ & $\begin{array}{l}\text { Cumulative } \\
\text { Percent }\end{array}$ \\
\hline \multirow{8}{*}{$\frac{\pi}{7}$} & internal audit & 9 & 25,0 & 25,0 & 25,0 \\
\hline & internal control & 7 & 19,4 & 19,4 & 44,4 \\
\hline & $\begin{array}{l}\text { custom error } \\
\text { and fraud }\end{array}$ & 1 & 2.8 & 2.8 & 472 \\
\hline & examination & & & & \\
\hline & external audit & 13 & 36,1 & 36,1 & 83,3 \\
\hline & tax audit & 4 & 11,1 & 11,1 & 94,4 \\
\hline & whistleblowing & 2 & 5,6 & 5,6 & 100,0 \\
\hline & Total & 36 & 100,0 & 100,0 & \\
\hline
\end{tabular}

When accounting professionals were asked about the most important and effective tools to prevent errors and fraud, 36,1\% answered this question as external audit. Then, 25\% suggested internal audit, 19,4\% recommended internal control, $11 \% 1$ advised tax audit, $5,6 \%$ mentioned whistle blowing and 2,8\% stated customer error and fraud examination.

Table 14: Reliability Statistics

\begin{tabular}{|c|c|c|}
\hline & Cronbach's Alpha & N of Items \\
\hline Error &, 733 & 12 \\
\hline Fraud &, 908 & 13 \\
\hline Ethics &, 630 & 14 \\
\hline Total &, 844 & 39 \\
\hline
\end{tabular}

Table 14 shows the Cronbach 's Alpha values for reliability analysis of the scales. Based on the reliability test, Cronbach's Alpha for the error scale is 0,733 . Also, Cronbach's Alpha for the fraud scale is 0,908 and it is 0,630 for the ethics scale. In total, the Cronbach's alpha is 0,844 . The scales meet the reliability criteria except ethics, since a minimum Cronbach's Alpha value of 0,7 is required (Nunnally, 1978).

Table 15: Frequency Distribution for Error Concept

\begin{tabular}{|c|c|c|c|c|c|c|c|c|c|c|c|c|}
\hline & & & disa & agree & & $\begin{array}{l}\text { ither } \\
\text { gree } \\
\text { nor } \\
\text { noree }\end{array}$ & & gree & & $\begin{array}{l}\text { ongly } \\
\text { gree }\end{array}$ & Mean & Sid \\
\hline & f & $\%$ & f & $\%$ & $f$ & $\%$ & $f$ & $\%$ & $f$ & $\%$ & & \\
\hline $\begin{array}{l}\text { 8. Errors occurred due to incorrect } \\
\text { data which was receved from } \\
\text { clients }\end{array}$ & 1 & 2,8 & 1 & 2,8 & 3 & 8,3 & 18 & 50 & 13 & 36,1 & 4,14 & 0,899 \\
\hline $\begin{array}{l}\text { 2. Errors occurred during } \\
\text { recoording }\end{array}$ & 0 & 0 & 0 & 0 & 4 & 11,1 & 24 & 66,7 & 8 & 22,2 & 4,11 & 0,575 \\
\hline $\begin{array}{l}\text { 6. Errors occurred du } \\
\text { inattention }\end{array}$ & 1 & 2,8 & 2 & 5,6 & 5 & 13,9 & 19 & 52,8 & 9 & 25 & 3,92 & 0,937 \\
\hline & 0 & 0 & 5 & 13,9 & 4 & 11,1 & 22. & 61,1 & 5 & 13,9 & 3,75 & 0,876 \\
\hline 1. Mathematical errors & 2 & 5,6 & 3 & 8,3 & 6 & 16,7 & 21 & 58,3 & 4 & 11,1 & 3,61 & 0,994 \\
\hline $\begin{array}{l}\text { 5. Errors made on the balance } \\
\text { sheet }\end{array}$ & 4 & 11,1 & 7 & 19,4 & 5 & 13,9 & 16 & 44,4 & 4 & 11,1 & 3,25 & 1,228 \\
\hline $\begin{array}{l}\text { 7. Errors occurred beccouse of } \\
\text { accounting } \\
\text { proferssionals }\end{array}$ & 4 & 11,1 & 7 & 19,4 & 6 & 16,7 & 17| & 47,2 & 2 & 5,6 & 3,17 & 1,159 \\
\hline $\begin{array}{r}\text { 3. Errors occurred } \\
\text { of acco }\end{array}$ & 4 & 11,1 & 10 & 27,8 & 4 & 11,1 & 14 & 38,9 & 4 & 11,1 & 3,11 & 1,26 \\
\hline $\begin{array}{l}\text { 9. Errorors occurred due to } \\
\text { offsetting receivables and debts, } \\
\text { as well as showing on the balance } \\
\text { sheet. }\end{array}$ & 6 & 16,7 & 10 & 27,8 & 10 & 27,8 & 7 & 19,4 & 3 & 8,3 & 2,75 & 1,204 \\
\hline $\begin{array}{l}\text { 10. Errors occurred due to wrong } \\
\text { recording to the general ledger }\end{array}$ & 7 & 19,4 & 15 & 41,7 & 6 & 16,7 & 5 & 13,9 & 3 & 8,3 & 2,5 & 1,207 \\
\hline $\begin{array}{l}\text { 12. Errors occurred due to } \\
\text { package program or system } \\
\text { (sottware) }\end{array}$ & 9 & 25 & 16 & 44,4 & 6 & 16,7 & 3 & 8,3 & 2 & 5,6 & 2,25 & 1,105 \\
\hline $\begin{array}{l}\text { 11. Errors occurred due to the } \\
\text { inadequacy of technology that } \\
\text { profeessionals use }\end{array}$ & 10 & 27,8 & 17 & 47,2 & 3 & 8,3 & 6 & 16,7 & 0 & 0 & 2,14 & 1,018 \\
\hline
\end{tabular}


When the frequency distributions are examined, it is determined that the highest mean belongs to the "Errors occurred due to incorrect data which was received from clients" expression with 4,14. "Errors occurred during recording" followed with a mean of 4,11 . The lowest mean belonged to the expression of "Errors occurred due to the inadequacy of technology that professionals use" with 2,14. The expression of "Errors occurred due to package program or system (software)" also had a low mean of 2,25.

Table 16: Frequency Distribution for Fraud Concept

\begin{tabular}{|c|c|c|c|c|c|c|c|c|c|c|c|c|}
\hline & & trongly & & isagree & & $\begin{array}{l}\text { either } \\
\text { agree } \\
\text { nor } \\
\text { sagagee }\end{array}$ & & Lgree & & $\begin{array}{l}\text { rongly } \\
\text { gree }\end{array}$ & & \\
\hline & & $\%$ & $f$ & $\%$ & f & $\%$ & f & $\%$ & $f$ & $\%$ & Mean & Sd \\
\hline $\begin{array}{l}\text { 2. Fraud is made in order to get } \\
\text { redit from banks. }\end{array}$ & & 2,8 & 9 & 25 & 1 & 2,8 & 19 & 52,8 & 6 & 16,7 & 3,56 & 1,132 \\
\hline $\begin{array}{l}\text { 9. Fraud is made in order to } \\
\text { provide benefits to the } \\
\text { organization by not showing the } \\
\text { real situation of the organization. }\end{array}$ & 2 & 5,6 & 6 & 16,7 & 9 & 25 & 14 & 38,9 & 5 & 13,9 & 3,39 & 1,103 \\
\hline 11. Fraud is made in & & 5,6 & 7 & 19,4 & 7 & 19,4 & 16 & 44,4 & 4 & 11,1 & 3,36 & 1,099 \\
\hline $\begin{array}{l}\text { 5. Fraud is a transaction made by } \\
\text { balance sheet masking. }\end{array}$ & & 13,9 & 6 & 16,7 & 5 & 13,9 & 14 & 38,9 & 6 & 16,7 & 3,28 & 1,323 \\
\hline $\begin{array}{l}\text { 10, Fraud is made } \\
\text { evade tax. }\end{array}$ & & 16,7 & & 13,9 & 5 & 13,9 & 16 & 44,4 & 4 & 11,1 & 3,19 & 1,305 \\
\hline 7. Fraud is a fabricate document. & 5 & 13,9 & 9 & 25 & 2 & 5,6 & 15 & 41,7 & 5 & 13,9 & 3,17 & 1,342 \\
\hline 1. Fraud is inte & 11 & 19,4 & $8^{8}$ & 22,2 & 3 & 8,3 & 11 & 30,6 & 7 & 19,4 & 3,08 & 1,461 \\
\hline $\begin{array}{l}\text { 2. Fraud is unregistered } \\
\text { transsactions, which were } \\
\text { undocumented. }\end{array}$ & 8 & 22,2 & & 19,4 & 6 & 16,7 & 10 & 27,8 & 5 & 13,9 & 2,92 & 1,402 \\
\hline $\begin{array}{l}\text { 4. Fraud is realized as simulated } \\
\text { account }\end{array}$ & 9 & 25 & 8 & 22,2 & 4 & 11,1 & 10 & 27,8 & 5 & 13,9 & 2,83 & 1,444 \\
\hline $\begin{array}{l}\text { 3. Fraud is recording before the } \\
\text { transsation takes place. }\end{array}$ & y & 25 & 0 & 22,2 & 5 & 13,9 & 11 & 30,6 & 3 & 8,3 & 2,75 & 1,36 \\
\hline $\begin{array}{l}\text { 6. Fraud is made on computer } \\
\text { (electronic fraud). }\end{array}$ & 7 & 19,4 & & 30,6 & 6 & 16,7 & 10 & 27,8 & 2 & 5,6 & 2,69 & 1,238 \\
\hline $\begin{array}{l}\text { 8. Fraud is made to hide the } \\
\text { corruption of business people. }\end{array}$ & & 19,4 & & 27,8 & 11 & 30,6 & 6 & 16,7 & 2 & 5,6 & 2,61 & 1,153 \\
\hline $\begin{array}{l}\text { 13. Members of profession commi } \\
\text { fraud to explot the gaps in tax } \\
\text { laws. }\end{array}$ & & & & & & 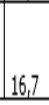 & & 25 & & & & 1,1 \\
\hline
\end{tabular}

When the frequency distributions are examined, it is determined that the expression of "Fraud is made in order to get credit from banks" had the highest mean of 3,56. This was followed by the expression of "Fraud is made in order to provide benefits to the organization by not showing the real situation of the organization" with a mean of 3,39. In the case of expressions with lowest means, it is determined that the expression of "Members of profession commit fraud to exploit the gaps in tax laws" had a mean score of 2,39. The expression of "Fraud is made to hide the corruption of business people" also had a low mean of 2,61.

\section{Table 17: Frequency Distribution for Ethics Concept}

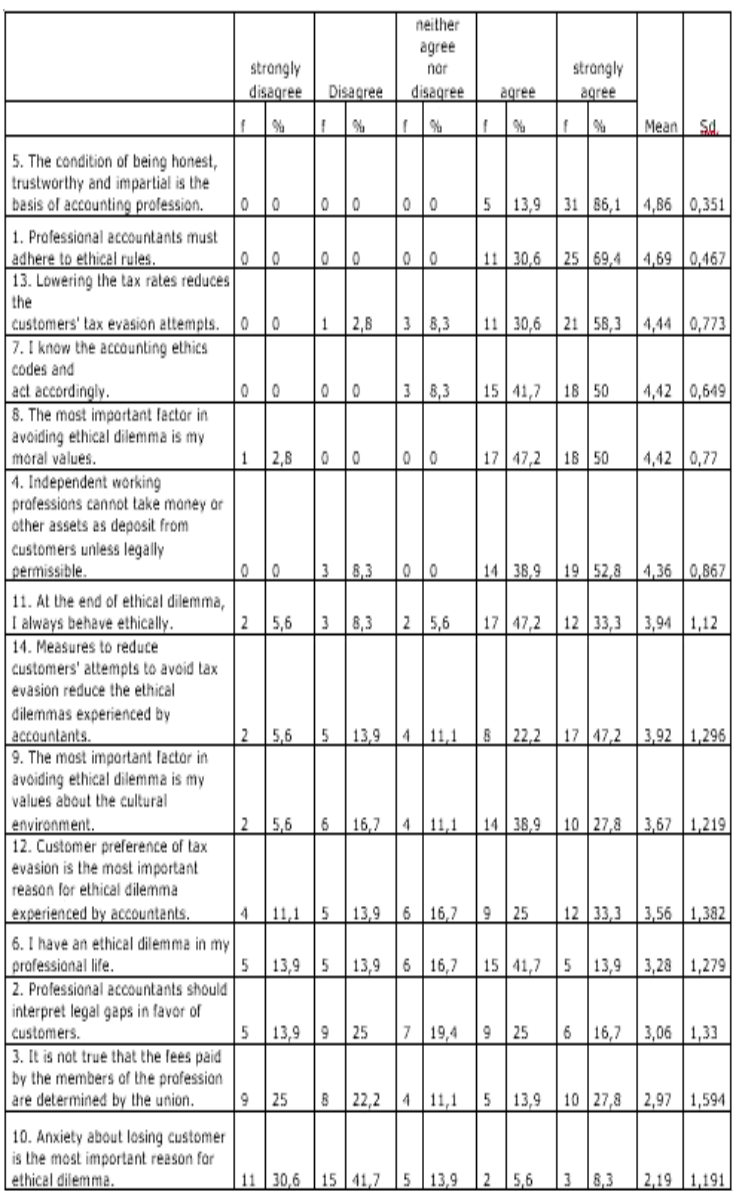

When the frequency distribution table of expressions is examined, the highest average, namely, the highest participation level is observed as 4,86. This expression states that, "The condition of being honest, trustworthy and impartial is the basis of accounting profession". This is followed by the expression of "Professional accountants must adhere to ethical rules" with a mean of 4,69 . The lowest mean belongs to the expression of "Anxiety about losing customer is the most important reason for ethical dilemma" with 2,19. Another expression with a low mean is "It is not true that the fees paid by the members of the profession are determined by the union", which scored 2,97.

\section{Conclusion}

A total of 36 accounting professionals participated in this research to reveal their thoughts and opinions. The majority of participants were male and the majority of participants were Certified Public Accountants (CPAs). The majority of participants had undergraduate (bachelor) degree. Also, a high percentage of participants had 1-3 employee(s) in their organizations and a great deal of accounting professionals had clients between 31 and 60 . 
A very limited number of participants reported employees in their organizations with penalty records. However, many accounting professionals were aware of colleagues who had disciplinary penalties. The majority of participants stated that, number of seminars/conferences organized by accounting chambers on errors and fraud is not adequate. A high percentage of participants stated that, supervision and disciplinary boards of professional accounting chambers fulfill their responsibilities partially. A high ratio of participants stated that, most important and effective tool to prevent errors and fraud was external audit.

According to research findings, errors mostly occurred due to incorrect data which was received from clients. Study also showed that, a big deal of errors also occurs during the recording process. However, errors occurring due to the inadequacy of technology that professionals were using and errors occurring due to package programs or systems (software) were low.

Another important finding of the research indicates that, fraud is mostly made in order to get credit from banks. Also, fraud is made in order to provide benefits to the organization by not showing the real situation of organization. On the other hand, based on study findings, members of profession are less likely to commit fraud to exploit the gaps in tax laws. Moreover, research findings signal that, fraud is not generally made to hide the corruption of business people.

Finally, in line with research findings, a great majority of accounting professionals believe that the condition of being honest, trustworthy and impartial is the basis of accounting profession. Also, parallel to the results of study, a high population agrees that professional accountants must adhere to ethical rules. But, from the perspective of accounting professionals, anxiety about losing customers is not the most important reason for ethical dilemma. Accountants also disagree with the expression, which denies that fees paid by the members of the profession are determined by the union.

\section{REFERENCES}

ACFE. (2014). Report to the Nations. US: ACFE.

ACFE. (2016). ACFE. Association of Certified Fraud Examiner. US: ACFE. Retrieved Mart 28, 2017, from ACEF web sites: https://www.acfe.com/rttn2016/docs/2016report-to-the-nations.pdf

ACFE. (2017). Retrieved Mart 28, 2017, from ACEF Web sitesi: http://www.acfe.com/fraudtriangle.aspx
Anuk, S. A. (2015). Muhasebe Hata ve Hileleri ile Muhasebe Mesleğinde Etik. İstanbul: Bahçeşehir Üniversitesi Sosyal Bilimler Enstitüsü, 54-103.

Baskan, T. D. (2013). Muhasebe Hata ve Hilelerinin Önlemesinde Băğmsız Denetimin Rolü ve Etkinliği: Bir Uygulama. Kırıkkale: Kırıkkale Üniversitesi Sosyal Bilimler Enstitüsü, 184186.

Bayrakl1, H. H., Erkan, M., \& Elitaş, C. (2012). Muhasebe ve Vergi Denetiminde Muhasebe Hata ve Hileleri. Bursa: Evin Yayınevi, 19-20.

Bayraktar, A. (2007). Türkiye'de Muhasebe Hileleri Tarihi. Edirne: Trakya Üniversitesi Sosyal Bilimler Enstitüsü, 3.

Bierstaker, J. L., Brody, R. G., \& Pacini, C. (2006). Accountants' Perceptions Regarding Fraud Detection and Prevention Method. Managerial Auditing Journal, 520-535.

Bonner, S. E., Palmrose, Z. V., \& Young, S. M. (1998, October). Fraud Type and Auditor Litigation: An Analysis of sec Accounting and Auditing Enforcement Releases. American Accounting Association, pp. 503-532.

Brumellgroup. (2015, Mart 25). Retrieved Mart 28, 2017, from brumellgroup web sitesi: http://brumellgroup.com/news/the-fraudtriangle-theory/

Büyükmirza, K. (2016). maliyet ve yönetim muhasebesi. Ankara: Gazi Kitabevi, 23.

Durtschi, C., Hillison, W., \& Pacini, C. (2004). The Effective Use of Benford's Law to Assist in Detecting Fraud in Accounting Data. Journal of Forencsic Accounting, 17-34.

Elliott, B., \& Elliott, J. (2011). Financial Accounting and Reporting. London: Pearson Education, 22.

Erdoğan, M., Elitaş, C., Erkan, M., \& Aydemir, O. (2014). Muhasebe Hilelerinin Denetiminde Benford Yasasl. Ankara: Gazi Kitabevi, 44-46.

Karaman, E. S. (2015). Muhasebe Meslek Etiği ve Muhasebe Meslek Mensuplarının Etik Kurallara Bakışı (Balıkesir İli Örneği). Ankara: Gazi Üniversitesi Sosyal Bilimler Enstitüsü, 47.

Keskin, S. (2014). Muhasebe Hata ve Hileleri Karşısında Etik Tutumlar: Meslek Mensupları Üzerine Bir Araştırma. Isparta: Süleyman Demirel Üniversitesi Sosyal Bilimler Enstitüsü, 131. 
Kirik, Z. (2007). Muhasebe Hata ve Hileleri ile Muhasebe Mesleğinde Etik: Afyankarahisar'da Muhasebeciler Üzerine Bir Araştırma. Eskişehir: Anadolu Üniversitesi Sosyal Bilimler Enstitüsü, 93-94.

Kirkos, E., Spathis, C., \& Manolopoulos, Y. (2007). Data Mining Techniques for Detections of Fraudulent Financial Statements. Expert Systems with Applications, 995-1003.

Kızıl, A., \& Kız1l, C. (2007). Accounting: Financial, Cost, Managerial. İstanbul: Bahar Yayınevi.

Kızıl, C., Akman, V., Aras, S., Erzin, N.O. (2015). Yalova İlinde İkamet Eden Muhasebe Meslek Mensuplarının Muhasebe Etik Algısı. Beykent Üniversitesi Sosyal Bilimler Dergisi (BUSBD), Cilt: 8, Say1: 1 (8/1), 6-31.

Kızıl, C., Çelik, İ. E., Akman, V. and Şener, S. (2016). Yaratıcı Muhasebe Yöntemleri ve Finansal Bilgilerin Manipülasyonu: Profesyonel Muhasebe Meslek Mensupları Üzerinde Örnek Bir Uygulama. Beykent Üniversitesi Sosyal Bilimler Dergisi (BUSBD), Cilt: 9, Sayı: 1 (9/1), 1-18.

Knapp, C. A., \& Knapp, M. C. (2001). The e€ects of experience and explicit fraud risk assessment in detecting fraud with analytical procedures. Accounting, Organizations and Society, 25-37.

Köpri, M., Civan, M., \& Kara, E. (2016, Mart 2). Hileli Finansal Raporlama Riskini Ortaya Çıkaran Faktörler: BIST'da Bir Uygulama. Journal of Accounting, Finance and Auditing Studies, pp. 271-291.

Marcos, L., \& Tayse, G. (2013, September-October). The Prevention of Error and Fraud in Accounting. International Journal of Advances in Management and Economics, pp. 125-131.

Nunnally, J. C. (1978). Psychometric theory (2nd ed.). New York: McGraw-Hill.

Okay, S. (2011). Muhasebe Hata ve Hilelerinin Meslek Etiği Açısından Irdelenmesi. Karaman: Karamanoğlu Mehmetbey Üniversitesi Sosyal Bilimler Enstitüsü, 110-111.

Özcan, A. (2016). Firm Characteristics and Accounting Fraud: A Multivariate Approach. Journal of Accounting, Finance and Auditing Studies, 128-144.

Sevilengül, O. (2016). Genel Muhasebe. Ankara: Gazi Kitapevi, 24.
TURMOB. (2017). Retrieved March 08, 2017, from TURMOB Web Site: http://www.turmob.org.tr/TurmobWeb/MBS/T urmobMevzuatDetay.aspx?param=CzOcfyLkk $\mathrm{sM}=$

Yardımcıŏlu, M., Koca, N., Günay, Y., \& Kocamaz, H. (2014). Yolsuzluk, muhasebe hileleri ve örnekleri. Kahramanmaraş Sütçü Imam Üniversitesi İIBF Dergisi, 4(2), 171-187 